\title{
Chemical Composition and Biological Activities of the Essential Oils from Three Melaleuca Species Grown in Tunisia
}

\author{
Ismail Amri ${ }^{1}$, Emilia Mancini ${ }^{2}$, Laura De Martino ${ }^{2}$, Aurelio Marandino ${ }^{2}$, Hamrouni Lamia ${ }^{1}$, \\ Hanana Mohsen ${ }^{3}$, Jamoussi Bassem ${ }^{4}$, Mariarosa Scognamiglio ${ }^{5}$, Ernesto Reverchon ${ }^{5}$ and \\ Vincenzo De Feo $^{2, *}$
}

1 Laboratory for Forest Ecology, National Institute for Research in Rural Engineering, Water and Forests, BP 10, 2080 Ariana, Tunisie; E-Mails: amri_amri@live.fr(I.A.); hamrounilam@yahoo.fr (H.L.)

2 Department of Pharmaceutical and Biomedical Sciences, University of Salerno, Via Ponte Don Melillo, 84084 Fisciano (Salerno), Italy; E-Mails: emancini@unisa.it (E.M.); 1demartino@unisa.it (L.M.); aureliomarandino@libero.it (A.M.)

3 Plant Molecular Physiology Laboratory, Center of Biotechnology of Borj-Cèdria, BP 901, 2050 Hammam-Lif, Tunisie; E-Mail: punto80@yahoo.com

4 Chemistry Laboratory, Higher Institute of Education and Continuous Training, 43 Rue de la Liberté, 2019 Le Bardo, Tunisie; E-Mail: jamoussi_bassem@yahoo.fr

5 Department of Industrial Engineering, University of Salerno, via Ponte Don Melillo, 84084 Fisciano (Salerno), Italy; E-Mails: mrscogna@unisa.it (M.S.); ereverchon@unisa.it (E.R.)

* Author to whom correspondence should be addressed; E-Mail: defeo@unisa.it; Tel.: +39-089-969-751; Fax: +39-089-969-602.

Received: 25 September 2012; in revised form: 25 October 2012 / Accepted: 29 November 2012 / Published: 5 December 2012

Abstract: The chemical composition of the essential oils of Melaleuca armillaris Sm.,
Melaleuca styphelioides Sm. and Melaleuca acuminata F. Muell., collected in Tunisia, was
studied by means of GC and GC-MS analysis. In all, 46 compounds were identified, 38 for
M. armillaris, 20 for M. acuminata and eight for M. styphelioides, respectively. The
presence of a sesquiterpenic fraction $(52.2 \%)$ characterized the oil from M. armillaris;
M. sthypheliodes oil was rich in methyl eugenol, a phenolic compound (91.1\%), while
M. acuminata oil is mainly constituted by oxygenated monoterpenoids (95.6\%). The
essential oils were evaluated for their in vitro potentially phytotoxic activity against
germination and initial radicle growth of Raphanus sativus L., Lepidium sativum L.,
Sinapis arvensis L., Triticum durum L. and Phalaris canariensis L. seeds. The radicle 
elongation of five seeds was inhibited at the highest doses tested, while germination of all seeds was not affected. Moreover, the essential oils showed low antimicrobial activity against eight selected microorganisms.

Keywords: Melaleuca acuminata; Melaleuca armillaris; Melaleuca styphelioides; phytotoxic activity; antimicrobial activity

\section{Introduction}

The genus Melaleuca (family Myrtaceae, subfamily Leptospermoideae) consists of about 230 species rich in volatile oils. Several studies demonstrated the efficacy of some Melaleuca essential oils against different types of bacteria and fungi [1-4], as in the case of Melaleuca alternifolia essential oil against methicillin-resistant Staphylococcus aureus (MRSA), Legionella pneumophila, and Staphylococcus aureus [5].

Essential oils are becoming more popular, because many synthetic drugs are connected with unpleasant side effects, such as nephrotoxicity or ototoxicity. Volatile oils also represent an interesting alternative due to an emerging resistance of microorganisms against synthetic agents. Essential oils can exert not only bacteriostatic and bactericidal effects, but also demonstrate activity against fungi and yeasts [5].

Moreover, in the past, it seemed that certain Melaleuca species may have allelopathic properties, resulting in an inhibition of other species in the same ecosystem [6]. The bare ground in Melaleuca forests was reported as an example of allelopathy in this genus [7].

Melaleuca armillaris $\mathrm{Sm}$. is one of the most widely cultivated melaleucas. It is commonly known as Bracelet Honey Myrtle and grows into a large spreading shrub or small tree. Literature reports about M. armillaris remain scarce. GC/MS investigations of its essential oil revealed the presence of 1,8-cineole as the main component [8-12]. Only little information could be found in the literature about the composition of Melaleuca styphelioides Sm. oils. Farag and coworkers [12] reported that the essential oil of this species contained mainly caryophyllene oxide (43.8\%) and (-)-spathulenol (9.7\%). Previously, the same authors [13] reported that the essential oil of M. styphelioides contained mainly caryophyllene (49.9\%) and methyl eugenol (26.6\%). Only a few reports are available about Melaleuca acuminata F. Muell. [14,15].

In continuation of our studies on the possible phytotoxic and antimicrobial activity of essential oils from plants collected in the Mediterranean area [16,17], we studied the chemical composition of the essential oils from Melaleuca armillaris, M. acuminata and M. styphelioides and their possible in vitro effects against germination and initial radicle elongation of Raphanus sativus L. (radish), Lepidium sativum L. (garden cress), Sinapis arvensis L. (wild mustard), Triticum durum L. (wheat) and Phalaris canariensis L. (canary grass) and the antimicrobial activity against eight selected microorganism. 


\section{Results and Discussion}

\subsection{Chemical Composition of the Essential Oils}

Hydrodistillation yielded $0.65 \%, 0.53 \%$ and $0.35 \%$ of essential oil (on a dry mass basis) for M. armillaris, M. acuminata and $M$. stypheliodes, respectively. Table 1 shows the chemical composition of the three Melaleuca oils; compounds are listed according to their elution order on a HP-5MS column. In all, 46 compounds were identified, 38 for M. armillaris, accounting for 99.3\% of the total oil, 20 for M. acuminata, accounting for $99.7 \%$ of the total oil, and eight for M. styphelioides (92.4\%), respectively.

Table 1. Percent composition of Melaleuca armillaris, Melaleuca acuminata and Melaleuca styphelioides essential oils.

\begin{tabular}{|c|c|c|c|c|c|c|}
\hline Compound & $\mathbf{R I}^{\mathbf{a}}$ & $\mathbf{R I}^{\mathbf{b}}$ & $\begin{array}{c}\text { Melaleuca } \\
\text { armillaris }\end{array}$ & $\begin{array}{l}\text { Melaleuca } \\
\text { acuminata }\end{array}$ & $\begin{array}{c}\text { Melaleuca } \\
\text { styphelioides }\end{array}$ & Identification $^{c}$ \\
\hline$\alpha$-Pinene & 935 & 1032 & - & - & 0.1 & $1,2,3$ \\
\hline Myrcene & 989 & 1162 & - & - & $\mathrm{t}$ & $1,2,3$ \\
\hline p-Cymene & 1017 & 1269 & - & - & 0.1 & $1,2,3$ \\
\hline 1,8-Cineole & 1022 & 1213 & 3.6 & 11.7 & - & $1,2,3$ \\
\hline Perillene & 1104 & 1429 & - & 0.1 & - & 1,2 \\
\hline$\alpha$-Campholenal & 1117 & 1497 & - & 0.7 & - & 1,2 \\
\hline Nopinone & 1124 & 1597 & 0.4 & 3.0 & - & 1,2 \\
\hline trans-Pinocarveol & 1127 & 1664 & 6.9 & 25.1 & - & 1,2 \\
\hline Camphor & 1131 & 1532 & - & 1.2 & - & $1,2,3$ \\
\hline 1-Terpineol & 1133 & & - & 0.5 & - & 1,2 \\
\hline trans-Sabinol & 1136 & 1720 & 0.6 & 1.6 & - & 1,2 \\
\hline trans-Verbenol & 1139 & 1683 & 0.4 & 1.1 & - & 1,2 \\
\hline Eucarvone & 1150 & 1932 & 1.4 & 6.4 & - & 1,2 \\
\hline Isoborneol & 1155 & 1633 & 0.5 & 0.3 & - & 1,2 \\
\hline Viridene & 1160 & & 1.3 & 2.4 & - & 1,2 \\
\hline Terpinen-4-ol & 1168 & 1611 & 0.4 & - & - & 1,2 \\
\hline$m$-Cymen-8-ol & 1179 & & 0.2 & - & - & 1,2 \\
\hline$p$-Cymen-8-ol & 1180 & 1856 & 0.1 & - & - & 1,2 \\
\hline$\alpha$-Terpineol & 1182 & 1706 & 7.7 & - & - & $1,2,3$ \\
\hline Dihydrocarveol & 1183 & 1755 & 9.0 & 23.6 & - & 1,2 \\
\hline Myrtenol & 1187 & 1804 & 6.4 & 12.3 & - & 1,2 \\
\hline Myrtenal & 1191 & 1648 & 0.8 & - & - & 1,2 \\
\hline cis-Dihydrocarvone & 1194 & 1620 & 0.5 & - & - & 1,2 \\
\hline Verbenone & 1196 & 1723 & 3.7 & 7.8 & - & 1,2 \\
\hline$p$-Cymen-9-ol & 1200 & & 0.1 & 0.2 & - & 1,2 \\
\hline 9-Decen-1-ol & 1260 & & 0.6 & - & - & 1,2 \\
\hline Citronellyl acetate & 1353 & 1662 & 0.5 & - & - & 1,2 \\
\hline cis-Piperitone oxide & 1360 & 1733 & 0.8 & - & - & 1,2 \\
\hline Methyl eugenol & 1401 & 2016 & - & - & 91.1 & 1,2 \\
\hline 4,8- $\beta$-epoxy-Caryophyllane & 1424 & & 0.4 & - & - & 1,2 \\
\hline cis- $\alpha$-Ambrinol & 1435 & & 0.6 & - & - & 1,2 \\
\hline
\end{tabular}


Table 1. Cont.

\begin{tabular}{|c|c|c|c|c|c|c|}
\hline Compound & $\mathbf{R I}^{\mathrm{a}}$ & $\mathbf{R I}^{\mathbf{b}}$ & $\begin{array}{c}\text { Melaleuca } \\
\text { armillaris }\end{array}$ & $\begin{array}{l}\text { Melaleuca } \\
\text { acuminata }\end{array}$ & $\begin{array}{c}\text { Melaleuca } \\
\text { styphelioides }\end{array}$ & Identification $^{c}$ \\
\hline allo-Aromadendrene & 1446 & 1661 & - & - & 0.2 & 1,2 \\
\hline Aromadendrene & 1453 & 1628 & 4.1 & - & - & 1,2 \\
\hline$\gamma$-Himachalene & 1483 & & 1.5 & - & - & 1,2 \\
\hline 10-Undecen-1-ol, acetate & 1495 & & 0.6 & - & - & 1,2 \\
\hline cis-Calamenene & 1511 & & 19.0 & - & - & 1,2 \\
\hline Germacrene B & 1539 & 1854 & 1.8 & 0.6 & - & 1,2 \\
\hline Spathulenol & 1562 & 2150 & 4.4 & 0.3 & 0.4 & 1,2 \\
\hline Caryophyllene oxide & 1565 & 2008 & 0.8 & 0.6 & 0.4 & $1,2,3$ \\
\hline Globulol & 1568 & 2098 & 1.2 & - & - & 1,2 \\
\hline Guaiol & 1575 & 2108 & 1.3 & - & - & 1,2 \\
\hline$\beta$-Atlantol & 1586 & & 0.5 & - & 0.1 & 1,2 \\
\hline 1-epi-Cubenol & 1591 & 2088 & 0.5 & 0.2 & - & 1,2 \\
\hline Torreyol & 1615 & & 15.1 & - & - & 1,2 \\
\hline$\gamma$-Eudesmol & 1623 & 2173 & 0.7 & - & - & 1,2 \\
\hline Methyl jasmonate & 1628 & & 0.6 & - & - & 1,2 \\
\hline$\alpha$-Eudesmol & 1633 & 2250 & 0.3 & - & - & 1,2 \\
\hline Total compounds & & & 99.3 & 99.7 & 92.4 & \\
\hline Monoterpene hydrocarbons & & & - & - & 0.2 & \\
\hline Oxygenated Monoterpenes & & & 44.6 & 95.6 & - & \\
\hline Sesquiterpene hydrocarbons & & & 26.4 & 0.6 & 0.2 & \\
\hline Oxygenated Sesquiterpenes & & & 25.2 & 1.1 & 0.9 & \\
\hline Phenolic compound & & & - & - & 91.1 & \\
\hline Carbonylic compounds & & & 1.2 & - & - & \\
\hline Non terpenes & & & 1.3 & 2.4 & - & \\
\hline Others & & & 0.6 & - & - & \\
\hline
\end{tabular}

${ }^{a}$ Kovats retention index on HP-5 MS column; ${ }^{b}$ Kovats retention index on HP Innowax; ${ }^{\mathrm{c}} 1=$ Kovats retention index, 2 = mass spectrum, $3=$ co-injection with authentic compound; $t=$ trace, less than $0.05 \%$.

In the oil from $M$. armillaris, the oxygenated monoterpenoids amounted to $44.6 \%$; on the other hand, the total sesquiterpenic fraction amounted to $51.6 \%$ of the total oil. The main compounds are the sesquiterpene cis-calamenene (19.0\%) and the oxygenated sesquiterpene torreyol (15.1\%). Other compounds, in a lesser amount, are dihydrocarveol $(9.0 \%)$ and $\alpha$-terpineol $(7.7 \%)$, both oxygenated monoterpenoids. In the literature, Chabir and coworkers [8,9] reported 1,8-cineole $(85.8 \%)$ as the most abundant compound in M. armillaris. The major compound in the essential oil of $M$. styphelioides was methyl eugenol (91.1\%), a phenolic compound. In the literature, Farag and coworkers [12] reported that the essential oil of this species contained mainly caryophyllene oxide (43.8\%), followed by (-)-spathulenol (9.7\%). In another paper [13], the same authors reported that the essential oil of this species contained mainly caryophyllene (50.0\%) and methyl eugenol (26.6\%).

In the oil from $M$. acuminata, the oxygenated monoterpenoids amounted to $95.6 \%$, with a total sesquiterpenes amount of $1.7 \%(0.6 \%$ sesquiterpene hydrocarbons and $1.1 \%$ of oxygenated sesquiterpenes) of the total oil. trans-Pinocarveol (25.1\%), dihydrocarveol (23.6\%), myrtenol (12.3\%) and 1,8-cineole $(11.7 \%)$ were the most abundant among the oxygenated monoterpenes. 
In the literature, only two references reported the chemical composition of the essential oil of M. acuminata: Smith and coworkers [14,15] reported that cineole was the main component of the essential oil of M. acuminata.

\subsection{Phytotoxic Activity}

The three essential oils were evaluated for their phytotoxic activity against germination and radicle elongation (Table 2) of radishes and garden cress, two species frequently utilized in biological assays, and of wild mustard, wheat and canary grass, three weed species.

Table 2. Phytotoxic activity of the essential oils of Melaleuca armillaris, Melaleuca styphelioides and Melaleuca acuminata against germination and radicle elongation of Sinapis arvensis, Triticum durum, Phalaris canariensis, Raphanus sativus and Lepidium sativum, $120 \mathrm{~h}$ after sowing. Data are expressed in centimeter.

\begin{tabular}{|c|c|c|c|c|c|c|c|}
\hline \multicolumn{4}{|c|}{ Sinapis arvensis Germinated seeds \pm SD $(\mathrm{cm})$} & \multicolumn{4}{|c|}{ Sinapis arvensis Radicle elongation \pm SD $(\mathrm{cm})$} \\
\hline Doses & $\begin{array}{l}\text { Melaleuca } \\
\text { armillaris } \\
\end{array}$ & $\begin{array}{c}\text { Melaleuca } \\
\text { styphelioides }\end{array}$ & $\begin{array}{l}\text { Melaleuca } \\
\text { acuminata } \\
\end{array}$ & Doses & $\begin{array}{l}\text { Melaleuca } \\
\text { armillaris } \\
\end{array}$ & $\begin{array}{c}\text { Melaleuca } \\
\text { styphelioides }\end{array}$ & $\begin{array}{l}\text { Melaleuca } \\
\text { acuminata } \\
\end{array}$ \\
\hline Control & $8.8 \pm 0.8$ & $8.8 \pm 0.8$ & $8.8 \pm 0.8$ & Control & $1.4 \pm 0.7$ & $1.4 \pm 0.7$ & $1.4 \pm 0.7$ \\
\hline $0.062 \mu \mathrm{g} / \mathrm{mL}$ & $9.2 \pm 0.6$ & $9.2 \pm 0.6$ & $9.8 \pm 0.6$ & $0.062 \mu \mathrm{g} / \mathrm{mL}$ & $1.2 \pm 0.7$ & $1.3 \pm 0.6$ & $1.9 \pm 0.8 * *$ \\
\hline $0.125 \mu \mathrm{g} / \mathrm{mL}$ & $8.3 \pm 1.4$ & $9.9 \pm 0.6$ & $9.4 \pm 0.6$ & $0.125 \mu \mathrm{g} / \mathrm{mL}$ & $1.3 \pm 0.5$ & $1.4 \pm 0.6$ & $1.5 \pm 0.9$ \\
\hline $0.25 \mu \mathrm{g} / \mathrm{mL}$ & $8.5 \pm 1.6$ & $9.2 \pm 0.6$ & $9.8 \pm 0.6$ & $0.25 \mu \mathrm{g} / \mathrm{mL}$ & $1.0 \pm 0.4$ & $1.1 \pm 0.5$ & $1.4 \pm 0.8$ \\
\hline $0.625 \mu \mathrm{g} / \mathrm{mL}$ & $7.9 \pm 1.4$ & $9.9 \pm 0.6$ & $10.0 \pm 0.0 *$ & $0.625 \mu \mathrm{g} / \mathrm{mL}$ & $2.3 \pm 1.3 *$ & $1.0 \pm 0.6$ & $1.1 \pm 0.4$ \\
\hline $1.25 \mu \mathrm{g} / \mathrm{mL}$ & $9.2 \pm 0.6$ & $9.9 \pm 0.6$ & $9.8 \pm 0.6$ & $1.25 \mu \mathrm{g} / \mathrm{mL}$ & $1.7 \pm 1.0$ & $1.3 \pm 0.9$ & $1.0 \pm 0.6 * *$ \\
\hline $2.5 \mu \mathrm{g} / \mathrm{mL}$ & $8.8 \pm 1.2$ & $9.5 \pm 1.1$ & $9.8 \pm 0.6$ & $2.5 \mu \mathrm{g} / \mathrm{mL}$ & $1.0 \pm 0.4$ & $1.2 \pm 0.7$ & $0.9 \pm 0.6 * *$ \\
\hline \multicolumn{4}{|c|}{ Triticum durum Germinated seeds \pm SD $(\mathrm{cm})$} & \multicolumn{4}{|c|}{ Triticum durum Radicle elongation \pm SD $(\mathrm{cm})$} \\
\hline Doses & $\begin{array}{l}\text { Melaleuca } \\
\text { armillaris } \\
\end{array}$ & $\begin{array}{c}\text { Melaleuca } \\
\text { styphelioides }\end{array}$ & $\begin{array}{l}\text { Melaleuca } \\
\text { acuminata } \\
\end{array}$ & Doses & $\begin{array}{l}\text { Melaleuca } \\
\text { armillaris } \\
\end{array}$ & $\begin{array}{c}\text { Melaleuca } \\
\text { styphelioides }\end{array}$ & $\begin{array}{l}\text { Melaleuca } \\
\text { acuminata } \\
\end{array}$ \\
\hline Control & $8.3 \pm 0.9$ & $8.3 \pm 0.9$ & $8.3 \pm 0.9$ & Control & $4.4 \pm 2.3$ & $4.4 \pm 2.3$ & $4.4 \pm 2.3$ \\
\hline $0.062 \mu \mathrm{g} / \mathrm{mL}$ & $8.7 \pm 1.2$ & $9.1 \pm 1.3$ & $8.0 \pm 1.4$ & $0.062 \mu \mathrm{g} / \mathrm{mL}$ & $4.7 \pm 2.3$ & $4.7 \pm 1.9$ & $4.0 \pm 1.7$ \\
\hline $0.125 \mu \mathrm{g} / \mathrm{mL}$ & $8.7 \pm 0.6$ & $7.4 \pm 3.4$ & $8.6 \pm 1.1$ & $0.125 \mu \mathrm{g} / \mathrm{mL}$ & $4.5 \pm 2.2$ & $4.8 \pm 2.2$ & $4.7 \pm 1.9$ \\
\hline $0.25 \mu \mathrm{g} / \mathrm{mL}$ & $7.3 \pm 1.5$ & $8.0 \pm 1.3$ & $7.7 \pm 1.1$ & $0.25 \mu \mathrm{g} / \mathrm{mL}$ & $5.7 \pm 1.6 *$ & $5.3 \pm 1.7$ & $4.4 \pm 2.6$ \\
\hline $0.625 \mu \mathrm{g} / \mathrm{mL}$ & $8.7 \pm 0.6$ & $8.0 \pm 2.3$ & $8.0 \pm 1.1$ & $0.625 \mu \mathrm{g} / \mathrm{mL}$ & $3.2 \pm 1.9 *$ & $5.1 \pm 1.8$ & $4.2 \pm 2.0$ \\
\hline $1.25 \mu \mathrm{g} / \mathrm{mL}$ & $6.7 \pm 3.5$ & $9.9 \pm 1.1$ & $7.7 \pm 0.6$ & $1.25 \mu \mathrm{g} / \mathrm{mL}$ & $3.9 \pm 1.5$ & $4.9 \pm 1.8$ & $2.8 \pm 1.7 * *$ \\
\hline $2.5 \mu \mathrm{g} / \mathrm{mL}$ & $8.7 \pm 1.5$ & $9.6 \pm 1.7$ & $8.6 \pm 1.1$ & $2.5 \mu \mathrm{g} / \mathrm{mL}$ & $3.8 \pm 1.7$ & $4.0 \pm 1.8$ & $3.4 \pm 2.0$ \\
\hline \multicolumn{4}{|c|}{ Phalaris canariensis Germinated seeds \pm SD (cm) } & \multicolumn{4}{|c|}{ Phalaris canariensis Radicle elongation \pm SD (cm) } \\
\hline Doses & $\begin{array}{l}\text { Melaleuca } \\
\text { armillaris }\end{array}$ & $\begin{array}{c}\text { Melaleuca } \\
\text { styphelioides }\end{array}$ & $\begin{array}{l}\text { Melaleuca } \\
\text { acuminata }\end{array}$ & Doses & $\begin{array}{l}\text { Melaleuca } \\
\text { armillaris }\end{array}$ & $\begin{array}{c}\text { Melaleuca } \\
\text { styphelioides }\end{array}$ & $\begin{array}{l}\text { Melaleuca } \\
\text { acuminata }\end{array}$ \\
\hline Control & $8.8 \pm 0.9$ & $8.8 \pm 0.9$ & $8.8 \pm 0.9$ & Control & $3.1 \pm 1.2$ & $3.1 \pm 1.2$ & $3.1 \pm 1.2$ \\
\hline $0.062 \mu \mathrm{g} / \mathrm{mL}$ & $8.8 \pm 2.2$ & $9.0 \pm 0.6$ & $8.7 \pm 1.0$ & $0.062 \mu \mathrm{g} / \mathrm{mL}$ & $2.8 \pm 1.1$ & $3.2 \pm .3$ & $2.8 \pm 0.7$ \\
\hline $0.125 \mu \mathrm{g} / \mathrm{mL}$ & $9.2 \pm 1.6$ & $9.7 \pm 0.0$ & $9.7 \pm 0.0$ & $0.125 \mu \mathrm{g} / \mathrm{mL}$ & $3.0 \pm 1.4$ & $3.3 \pm 1.1$ & $3.4 \pm 1.2$ \\
\hline $0.25 \mu \mathrm{g} / \mathrm{mL}$ & $9.4 \pm 0.6 *$ & $8.1 \pm 1.1$ & $8.7 \pm 1.0$ & $0.25 \mu \mathrm{g} / \mathrm{mL}$ & $2.4 \pm 1.2$ & $3.7 \pm 1.3$ & $3.2 \pm 1.5$ \\
\hline $0.625 \mu \mathrm{g} / \mathrm{mL}$ & $9.2 \pm 0.6$ & $8.7 \pm 1.0$ & $9.4 \pm 0.6$ & $0.625 \mu \mathrm{g} / \mathrm{mL}$ & $2.6 \pm 1.2$ & $3.9 \pm 1.0$ & $2.5 \pm 0.9 *$ \\
\hline $1.25 \mu \mathrm{g} / \mathrm{mL}$ & $10.6 \pm 0.0 * *$ & $8.7 \pm 1.7$ & $8.4 \pm 1.4$ & $1.25 \mu \mathrm{g} / \mathrm{mL}$ & $2.6 \pm 0.8$ & $3.2 \pm 1.3$ & $1.6 \pm 1.4 * * *$ \\
\hline $2.5 \mu \mathrm{g} / \mathrm{mL}$ & $9.2 \pm 0.6$ & $8.4 \pm 0.6$ & $8.1 \pm 1.5$ & $2.5 \mu \mathrm{g} / \mathrm{mL}$ & $3.5 \pm 1.6$ & $2.8 \pm 1.1$ & $2.7 \pm 0.7$ \\
\hline
\end{tabular}


Table 2. Cont.

\begin{tabular}{|c|c|c|c|c|c|c|c|}
\hline \multicolumn{4}{|c|}{ Raphanus sativus Germinated seeds \pm SD (cm) } & \multicolumn{4}{|c|}{ Raphanus sativus Radicle elongation \pm SD (cm) } \\
\hline Doses & $\begin{array}{c}\text { Melaleuca } \\
\text { armillaris }\end{array}$ & $\begin{array}{c}\text { Melaleuca } \\
\text { styphelioides }\end{array}$ & $\begin{array}{l}\text { Melaleuca } \\
\text { acuminata }\end{array}$ & Doses & $\begin{array}{c}\text { Melaleuca } \\
\text { armillaris }\end{array}$ & $\begin{array}{c}\text { Melaleuca } \\
\text { styphelioides }\end{array}$ & $\begin{array}{l}\text { Melaleuca } \\
\text { acuminata }\end{array}$ \\
\hline Control & $9.3 \pm 0.7$ & $9.3 \pm 0.7$ & $9.3 \pm 0.7$ & Control & $6.1 \pm 2.8$ & $6.1 \pm 2.8$ & $6.1 \pm 2.8$ \\
\hline $0.062 \mu \mathrm{g} / \mathrm{mL}$ & $10.0 \pm 0.0$ & $9.6 \pm 0.0$ & $9.0 \pm 0.6$ & $0.062 \mu \mathrm{g} / \mathrm{mL}$ & $6.7 \pm 3.3$ & $6.0 \pm 2.5$ & $4.8 \pm 2.4$ \\
\hline $0.125 \mu \mathrm{g} / \mathrm{mL}$ & $10.0 \pm 0.0$ & $8.9 \pm 0.6$ & $10.1 \pm 0.6$ & $0.125 \mu \mathrm{g} / \mathrm{mL}$ & $6.0 \pm 3.4$ & $4.0 \pm 2.4 * *$ & $5.0 \pm 2.2$ \\
\hline $0.25 \mu \mathrm{g} / \mathrm{mL}$ & $10.0 \pm 0.0$ & $9.9 \pm 0.6$ & $9.4 \pm 0.0$ & $0.25 \mu \mathrm{g} / \mathrm{mL}$ & $6.4 \pm 3.2$ & $5.3 \pm 2.4$ & $4.5 \pm 2.3$ \\
\hline $0.625 \mu \mathrm{g} / \mathrm{mL}$ & $9.7 \pm 0.6$ & $9.6 \pm 0.0$ & $9.7 \pm 1.1$ & $0.625 \mu \mathrm{g} / \mathrm{mL}$ & $7.1 \pm 2.9$ & $5.1 \pm 2.9$ & $4.4 \pm 2.4$ \\
\hline $1.25 \mu \mathrm{g} / \mathrm{mL}$ & $9.7 \pm 0.6$ & $8.9 \pm 0.6$ & $8.6 \pm 1.6$ & $1.25 \mu \mathrm{g} / \mathrm{mL}$ & $6.1 \pm 2.9$ & $4.0 \pm 2.1 * *$ & $3.5 \pm 2.0 * * *$ \\
\hline $2.5 \mu \mathrm{g} / \mathrm{mL}$ & $9.7 \pm 0.6$ & $9.3 \pm 0.6$ & $9.7 \pm 1.6$ & $2.5 \mu \mathrm{g} / \mathrm{mL}$ & $6.3 \pm 2.9$ & $4.8 \pm 2.6$ & $4.2 \pm 2.4 *$ \\
\hline \multicolumn{4}{|c|}{ Lepidum sativum Germinated seeds \pm SD $(\mathrm{cm})$} & \multicolumn{4}{|c|}{ Lepidum sativum Radicle elongation \pm SD (cm) } \\
\hline Doses & $\begin{array}{c}\text { Melaleuca } \\
\text { armillaris }\end{array}$ & $\begin{array}{c}\text { Melaleuca } \\
\text { styphelioides }\end{array}$ & $\begin{array}{l}\text { Melaleuca } \\
\text { acuminata }\end{array}$ & Doses & $\begin{array}{c}\text { Melaleuca } \\
\text { armillaris }\end{array}$ & $\begin{array}{c}\text { Melaleuca } \\
\text { styphelioides }\end{array}$ & $\begin{array}{l}\text { Melaleuca } \\
\text { acuminata }\end{array}$ \\
\hline Control & $8.2 \pm 0.5$ & $8.2 \pm 0.5$ & $8.2 \pm 0.5$ & Control & $2.8 \pm 1.8$ & $2.8 \pm 1.8$ & $2.8 \pm 1.8$ \\
\hline $0.062 \mu \mathrm{g} / \mathrm{mL}$ & $8.2 \pm 0.0$ & $8.2 \pm 0.6$ & $9.2 \pm 1.0$ & $0.062 \mu \mathrm{g} / \mathrm{mL}$ & $2.7 \pm 1.5$ & $1.5 \pm 1.1 * * *$ & $2.7 \pm 2.1$ \\
\hline $0.125 \mu \mathrm{g} / \mathrm{mL}$ & $8.9 \pm 1.5$ & $8.7 \pm 0.6$ & $8.2 \pm 1.0$ & $0.125 \mu \mathrm{g} / \mathrm{mL}$ & $2.5 \pm 1.2$ & $1.61 .1 * * *$ & $2.7 \pm 1.5$ \\
\hline $0.25 \mu \mathrm{g} / \mathrm{mL}$ & $9.5 \pm 0.6$ & $8.5 \pm 1.6$ & $9.2 \pm 1.0$ & $0.25 \mu \mathrm{g} / \mathrm{mL}$ & $2.3 \pm 2.2$ & $1.8 \pm 1.4 * * *$ & $2.7 \pm 2.1$ \\
\hline $0.625 \mu \mathrm{g} / \mathrm{mL}$ & $8.5 \pm 0.6$ & $8.5 \pm 0.9$ & $9.2 \pm 1.0$ & $0.625 \mu \mathrm{g} / \mathrm{mL}$ & $2.8 \pm 1.4$ & $1.1 \pm 1.0 * * *$ & $2.7 \pm 2.1$ \\
\hline $1.25 \mu \mathrm{g} / \mathrm{mL}$ & $9.2 \pm 1.0$ & $7.5 \pm 0.9$ & $8.9 \pm 1.5$ & $1.25 \mu \mathrm{g} / \mathrm{mL}$ & $1.9 \pm 1.4$ & $1.8 \pm 1.1 * *$ & $2.2 \pm 1.8$ \\
\hline $2.5 \mu \mathrm{g} / \mathrm{mL}$ & $7.2 \pm 1.0$ & $8.7 \pm 0.6$ & $7.9 \pm 1.5$ & $2.5 \mu \mathrm{g} / \mathrm{mL}$ & $2.9 \pm 1.4$ & $1.9 \pm 1.0 * *$ & $2.6 \pm 2.4$ \\
\hline
\end{tabular}

The oils seem to be ineffective against germination, but they affected the radicle elongation of the five tested seeds. The essential oil of $M$. styphelioides, at all doses tested, significantly inhibited the radicle elongation of garden cress. The radicle elongation of wild mustard and radish were inhibited by $M$. acuminata oil at the highest doses $(2.5 \mu \mathrm{g} / \mathrm{mL}, 1.25 \mu \mathrm{g} / \mathrm{mL})$ used. At doses of 1.25 and $0.625 \mu \mathrm{g} / \mathrm{mL}$, the essential oil of $M$. acuminata significantly inhibited the radicle elongation of canary grass (Table 2). The difference in biological activity of the oils could be attributed to their different chemical composition.

On the other hand, the oil of $M$. acuminata was rich in oxygenated monoterpenoids, trans-pinocarveol, dihydrocarveol, myrtenol and 1,8-cineole. trans-Pinocarveol was reported as one of the main components of the strong phytotoxic oil from a Cistus ladanifer L. population [18].

Yatagai and coworkers [19] reported that the leaf oil of Melelauca bracteata F. Muell. had the strongest germination and growth-inhibition activity against radish seeds.

The roots were probably more sensitive than shoots to the phytotoxic activity of the oil; the process of germination was active while the oil probably affected the elongation process. Such activity of the essential oils could help to explain the ecological role of the genus Melaleuca in the Mediterranean area.

\subsection{Antimicrobial Activity}

The Minimum Inhibitory Concentration (MIC) and the Minimum Bactericidal Concentration $(\mathrm{MBC})$ values of the essential oils against eight selected microorganisms are reported in Table 3. 
Table 3. Minimum Inhibitory Concentration (MIC) and Minimum Bactericidal Concentration (MBC) Values $(\mu \mathrm{g} / \mathrm{mL})$ of essential oils from the three Melaleuca Species and MIC of the reference antibiotic, chloramphenicol. Results are the mean of three experiments.

\begin{tabular}{|c|c|c|c|c|c|c|c|}
\hline \multirow[t]{2}{*}{ Bacterial strain } & \multicolumn{2}{|c|}{$\begin{array}{c}\text { Melaleuca } \\
\text { styphelioides }\end{array}$} & \multicolumn{2}{|c|}{$\begin{array}{l}\text { Melaleuca } \\
\text { armillaris }\end{array}$} & \multicolumn{2}{|c|}{$\begin{array}{l}\text { Melaleuca } \\
\text { acuminata }\end{array}$} & \multirow[t]{2}{*}{ Chloramphenicol } \\
\hline & MIC $^{a}$ & $\mathbf{M B C}^{\mathbf{b}}$ & MIC & MBC & MIC & MBC & \\
\hline $\begin{array}{l}\text { Bacillus subtilis } \\
\text { ATCC } 6633\end{array}$ & 100 & $>100$ & 50 & 100 & 50 & n.a. & 12.5 \\
\hline $\begin{array}{l}\text { Staphylococcus aureus } \\
\text { ATCC } 25923\end{array}$ & 100 & $>100$ & 100 & $>100$ & 50 & 100 & 25 \\
\hline $\begin{array}{l}\text { Staphylococcus } \\
\text { epidermidis } \\
\text { ATCC } 12228\end{array}$ & 50 & 100 & 50 & n.a. & 12.5 & n.a. & 3.12 \\
\hline $\begin{array}{l}\text { Streptococcus faecalis } \\
\text { ATCC } 29212\end{array}$ & $>100$ & n.a. & $>100$ & n.a. & 100 & 100 & 25 \\
\hline $\begin{array}{l}\text { Escherichia coli } \\
\text { ATCC } 25922\end{array}$ & 100 & $>100$ & 50 & n.a. & 25 & 50 & 12.5 \\
\hline $\begin{array}{l}\text { Klebsiella pneumoniae } \\
\text { ATCC } 10031\end{array}$ & $>100$ & n.a. & 100 & $>100$ & 100 & $>100$ & 50 \\
\hline $\begin{array}{l}\text { Proteus vulgaris } \\
\text { ATCC } 13315\end{array}$ & $>100$ & n.a. & 50 & 100 & 50 & 100 & 25 \\
\hline $\begin{array}{l}\text { Pseudomonas aeuriginosa } \\
\text { ATCC } 27853\end{array}$ & $>100$ & n.a. & $>100$ & n.a. & $>100$ & n.a. & 100 \\
\hline
\end{tabular}

The essential oils showed inhibitory activity against the gram-positive pathogens, among which is $S$. epidermidis. Among gram-negative bacteria, E. coli was affected by the oil of M. armillaris and M. acuminata. The essential oil of M. acuminata was more active than other oils and presumably this activity is related to the high amounts of oxygenated monoterpenoids.

Farag and coworkers $[12,13]$ reported the effect of the essential oil from the leaves of M. armillaris, M. ericifolia (Smith), M. leucadendron (Linn.) and M. styphelioides against the growth of some microorganisms. The results demonstrated that the degree of the microbial inhibition is largely dependent on the species. M. ericifolia exhibited the highest inhibitory effects against Bacillus subtilis and Aspergillus niger. The antimicrobial properties of Melaleuca essential oil have been reported in several studies [20] Terpinen-4-ol is considered to be the principal active component of Melaleuca alternifolia Cheel (tea tree) oil [21-23]. Terpinen-4-ol could constitute an interesting alternative in the therapy of MRSA infections of the skin [5]. In the literature, it was reported that some members of the Myrtaceae family (Eucalyptus globulus and Melaleuca alternifolia) whose essential oil consisted mainly of monocyclic and bicyclic monoterpenes (e.g., 1,8-cineole and terpinen-4-ol) effectively inhibited the growth of drug-resistant bacterium strains [5]. 


\section{Experimental Section}

\subsection{Plant Material}

Leaves of Melaleuca armillaris, M. acuminata and M. styphelioides Sm. were collected from the Botanical Garden of the National Institute of Researches on Rural Engineering, Water and Forests (Ariana, Tunisia) in April 2011. Five samples were collected from more than five different trees, mixed for homogenization and used in three replicates for essential oil extractions. Specimens were identified by Dr. H. Lamia, and voucher specimens were deposited at the herbarium of the Laboratory of Forestry Ecology at the National Institute of Research on Rural Engineering, Water and Forest (Tunisia).

\subsection{Isolation of the Volatile Oils}

One hundred grams of dried leaves of each Melaleuca species were ground in a Waring blender and then, subjected to hydrodistillation for $3 \mathrm{~h}$ according to the standard procedure described in the European Pharmacopoeia [24].

The oils were solubilized in $n$-hexane, dried over anhydrous sodium sulphate and dried under $\mathrm{N}_{2}$ to remove hexane. Samples were stored at $+4{ }^{\circ} \mathrm{C}$ in the dark until tested and analyzed.

\subsection{GC-FID Analysis}

The GC-FID analysis was carried out on a Perkin-Elmer Sigma-115 gas chromatograph equipped with a flame ionization detector (FID) and a data handling processor. The separation was achieved using an apolar HP-5 MS fused-silica capillary column $(30 \mathrm{~m} \times 0.25 \mathrm{~mm}$ i.d., $0.25 \mu \mathrm{m}$ film thickness $)$. Column temperature: $40{ }^{\circ} \mathrm{C}$, with $5 \mathrm{~min}$ initial hold, and then to $270{ }^{\circ} \mathrm{C}$ at $2{ }^{\circ} \mathrm{C} / \mathrm{min}, 270{ }^{\circ} \mathrm{C}(20 \mathrm{~min})$; injection mode: splitless ( $1 \mu \mathrm{L}$ of a 1:1000 n-pentane solution). Injector and detector temperatures were $250{ }^{\circ} \mathrm{C}$ and $290{ }^{\circ} \mathrm{C}$, respectively. Analysis was also run by using a fused silica HP Innowax polyethylenglycol capillary column $(50 \mathrm{~m} \times 0.20 \mathrm{~mm}$ i.d., $0.25 \mu \mathrm{m}$ film thickness $)$. In both cases, helium was used as carrier gas $(1.0 \mathrm{~mL} / \mathrm{min})$.

\subsection{GC/MS Analysis}

The GC/MS analysis was performed on an Agilent 6,850 Ser. II apparatus, fitted with a fused silica DB-5 capillary column $(30 \mathrm{~m} \times 0.25 \mathrm{~mm}$ i.d., $0.33 \mu \mathrm{m}$ film thickness), coupled to an Agilent Mass Selective Detector MSD 5973; ionization energy voltage $70 \mathrm{eV}$; electron multiplier voltage energy $2000 \mathrm{~V}$. Mass spectra were scanned in the range 40-500 amu, scan time $5 \mathrm{scans} / \mathrm{s}$. Gas chromatographic conditions were as reported in the previous paragraph; transfer line temperature, $295{ }^{\circ} \mathrm{C}$.

\subsection{Identification of the Essential Oils Components}

Most constituents were identified by gas chromatography by comparison of their Kovats retention indices (Ri) with either those of the literature $[25,26]$ or with those of authentic compounds available in our laboratories. The Kovats retention indices were determined in relation to a homologous series of $n$-alkanes $\left(\mathrm{C}_{10}-\mathrm{C}_{35}\right)$ under the same operating conditions. Further identification was made by comparison of their mass spectra on both columns with either those stored in NIST 02 and Wiley 275 
libraries or with mass spectra from the literature [25,27] and a homemade library. The components relative concentrations were obtained by peak area normalization. No response factors were calculated.

\subsection{Biological Assay}

A bioassay based on germination and subsequent radicle growth was used to study the phytotoxic effects of the three essential oils on seeds of Raphanus sativus L. cv. "Saxa" (radish), Lepidium sativum L. (garden cress) and the three weed species Sinapis arvensis L. (wild mustard), Triticum durum L. (wheat) and Phalaris canariensis L. (canary grass). The seeds of radish and garden cress were purchased from Blumen srl (Piacenza, Italy), while mustard, wheat and canary grass were collected from wild plants. The seeds were surface sterilized in $95 \%$ ethanol for $15 \mathrm{~s}$ and sown in Petri dishes $(\varnothing=90 \mathrm{~mm})$ containing five layers of Whatman filter paper impregnated with distilled water ( $7 \mathrm{~mL}$, control) or a tested solution of the essential oil $(7 \mathrm{~mL})$ at the different assayed doses. The germination conditions were $20 \pm 1{ }^{\circ} \mathrm{C}$ with a natural photoperiod. The essential oils, in a water-acetone mixture (99.5:0.5), were assayed at the doses of $2.5,1.25,0.625,0.25,0.125$ and $0.062 \mu \mathrm{g} / \mathrm{mL}$. Controls performed with water-acetone mixture alone showed no appreciable differences in comparison with controls in water alone. Seed germination was observed directly in Petri dishes, each $24 \mathrm{~h}$. A seed was considered germinated when the protrusion of the root became evident [28]. After $120 \mathrm{~h}$ (on the fifth day), the effects on radicle elongation were measured in centimeter. Each determination was repeated three times, using Petri dishes containing 10 seeds each. Data are expressed as the mean $\pm \mathrm{SD}$ for both germination and radicle elongation. Data were ordered in homogeneous sets, and the Student's $t$ test of independence was applied [29].

\subsection{Determination of Minimum Inhibitory Concentration (MIC) and Minimum Bactericidal Concentration $(M B C)$}

The antibacterial activity was evaluated by determining the minimum inhibitory concentration (MIC) and the minimum bactericidal concentration (MBC) using the broth dilution method [30-32]. Eight bacterial species, selected as representative of the gram-positive and gram-negative classes, were tested: Staphylococcus aureus (ATTC 25923), Streptococcus faecalis (ATTC 29212), Bacillus subtilis (ATCC 6633), Escherichia coli (ATCC 25922), Pseudomonas aeruginosa (ATCC 27853), Staphylococcus epidermidis (ATCC 12228), Klebsiella pneumoniae (ATCC 10031) and Proteus vulgaris (ATCC 13315). The strains were maintained on Tryptone Soya agar (Oxoid, Milan, Italy); for the antimicrobial tests, Tryptone Soya broth (Oxoid, Milan, Italy) was used. In order to facilitate the dispersion of the oil in the aqueous nutrient medium, it was diluted with Tween 20 at a concentration of $10 \%$. Each strain was tested with a sample that was serially diluted in broth to obtain concentrations ranging from $100 \mu \mathrm{g} / \mathrm{mL}$ to $0.8 \mu \mathrm{g} / \mathrm{mL}$. The sample was previously sterilized with a $0.20 \mu \mathrm{m}$ Millipore filter. The sample was stirred, inoculated with $50 \mu \mathrm{L}$ of physiological solution containing $5 \times 10^{6}$ microbial cells and incubated for $24 \mathrm{~h}$ at $37{ }^{\circ} \mathrm{C}$. The MIC value was determined as the lowest concentration of the sample that did not permit any visible growth of the tested microorganism after incubation. The control, containing only Tween 20 instead of the essential oil, was not toxic to the microorganisms. Cultures, containing only sterile physiologic solution Tris buffer, were used as positive control. MBC was determined by subculture of the tubes with inhibition in $5 \mathrm{~mL}$ of sterile 
nutrient broth. After incubation at $37^{\circ} \mathrm{C}$, the tubes were observed. When the germs did not grow, the sample denoted a bactericidal action. Oil samples were tested in triplicate and the experiment was performed three times. The results are expressed as mean \pm SD. Chloramphenicol was used as reference drug [17].

\section{Conclusions}

Data obtained in this paper could be useful in the chemotaxonomic knowledge of the genus Melaleuca that consists of about 230 species, the chemistry of M. armillaris, M. styphelioides and M. acuminata being little known. Data on phytotoxic activities could help to explain the ecological role of genus Melaleuca in the Mediterranean area. The antimicrobial activity of the essential oil is in agreement with the uses of other Melaleuca species as antimicronial drugs.

\section{Conflict of Interest}

The authors declare no conflict of interest.

\section{References}

1. Liu, X.; Zu, Y.G.; Fu, Y.J.; Yao, L.P.; Gu, C.B.; Wang, W.; Efferth, T. Antimicrobial activity and cytotoxicity towards cancer cells of Melaleuca alternifolia (tea tree) oil. Eur. Food Res. Technol. 2009, 229, 247-253.

2. Jones, M.R.; Julia, E.J.; Victor, R. Steam distillation of tea tree (Melaleuca alternifolia) oil. J. Sci. Food Agric. 1992, 58, 49-53.

3. Southwell, I.A. Australian tea tree oil of Melaleuca terpinene-4-ol type. Chem. Aust. 1988, 55, 400-402.

4. Altman, P. Australian tea tree oil. Aust. J. Pharm. 1988, 69, 276-278.

5. Lang, G.; Buchbauer, G. A review on recent research results (2008-2010) on essential oils as antimicrobials and antifungals. A review. Flavour Frag. J. 2012, 27, 13-39.

6. Rice, E.L. Allelopathy, 2nd ed.; Academic Press: London, UK, 1984.

7. Yatagai, M. Allelopathy, control of plant ecosystem by plant chemical components: Chemical characteristics and activity of plant odor components. Aroma Res. 2007, 8, 408-413.

8. Chabir, N.; Romdhane, M.; Valentin, A.; Moukarzel, B.; Marzoug, H.N.; Brahim, N.B.; Mars, M.; Bouajila, J. Chemical study and antimalarial, antioxidant, and anticancer activities of Melaleuca armillaris (Sol Ex Gateau) Sm essential oil. J. Med. Food 2011, 14, 1383-1388.

9. Chabir, N.; Ben, Brahim, N.; Mars, M.; Romdhane, M. Influence of ultrasons on quality and quantity of essential oils Melaleuca armillaris cultivated in Tunisia. Acta Hortic. 2010, 853, 277-284.

10. Hayouni, E.A.; Bouix, M.; Abedrabba, M.; Leveau, J.Y.; Hamdi, M. Mechanism of action of Melaleuca armillaris (Sol. Ex Gaertu) Sm. essential oil on six LAB strains as assessed by multiparametric flow cytometry and automated microtiter-based assay. Food Chem. 2008, 111, $707-718$. 
11. Silva, C.J.; Barbosa, L.C.; Maltha, C.R.; Pinheiro, A.L.; Ismail, F.M. Comparative study of the essential oils of seven Melaleuca (Myrtaceae) species grown in Brazil. Flavour Frag. J. 2007, 22, 474-478.

12. Farag, R.S.; Shalaby, A.S.; El-Baroty, G.A.; Ibrahim, N.A.; Ali, M.A.; Hassan, E.M. Chemical and biological evaluation of the essential oils of different Melaleuca species. Phytother. Res. 2004, 18, 30-35.

13. Farag, R.S.; Daw, Z.Y.; Mahassen, M.A.; Safaa, H.M. Biochemical and biological studies on some tea trees (Melaleuca spp.) essential oil. Adv. Food Sci. 1998, 20, 153-162.

14. Smith, H.G.; Carter, P.G.; Read, J. Phellandrenes. II. J. Chem. Soc. Trans. 1924, 125, 930-940.

15. Smith, H.G. Occurrence of 1-phellandrene in the oil of Meleluca acuminata. J. Proc. R. Soc. N. S. W. 1922, 56, 159-161.

16. De Martino, L.; Mancini, E.; Marandino, A.; de Almeida, L.F.R.; de Feo, V. Chemistry and antigerminative activity of essential oils and monoterpenoids from Mediterranean Plants. Curr. Bioact. Compd. 2012, 8, 13-49.

17. De Martino, L.; de Feo, V.; Formisano, C.; Mignola, E.; Senatore, F. Chemical composition and antimicrobial activity of the essential oils from three chemotypes of Origanum vulgare L. ssp. hirtum (Link) Ietswaart growing wild in Campania (Southern Italy). Molecules 2009, 14, 2735-2746.

18. Verdeguer, M.; Blazquez, M.A.; Boira, H. Chemical composition and herbicidal activity of the essential oil from a Cistus ladanifer L. population from Spain. Nat. Prod. Res. 2012, 26, 1602-1609.

19. Yatagai, M.; Ohira, T.; Nakashima, K. Composition, miticidal activity and growth regulation effect on radish seeds of extracts from Melaleuca species-A mechanism of toxin transport from Eucayptus globulus. Biochem. Syst. Ecol. 1998, 26, 713-722.

20. Bassolé, I.H.N.; Juliani, H.R. Essential Oils in Combination and Their Antimicrobial Properties. Molecules 2012, 17, 3989-4006.

21. Griffin, G.S.; Wyllie, G.S.; Markham, L.J.; Leach, D.N. The role of structure and molecular properties of terpenoids in determining their antimicrobial activity. Flavour Frag. J. 1999, 14, 322-332.

22. Carson, C.F.; Riley, T.V. Antimicrobial activity of the major components of the essential oil of Melaleuca alternifolia. J. Appl. Microb. 1995, 78, 264-269.

23. Southwell, I.A.; Hayes, A.J.; Markham, J.L.; Leach, D.N. The search for optimally bioactive Australian tea tree oil. Acta Hortic. 1993, 334, 265-275.

24. European Pharmacopoeia, 5th ed.; Council of Europe: Strasbourg Cedex, France, 2004; Volume I, pp. 217-218.

25. Jennings, W.; Shibamoto, T. Qualitative Analysis of Flavour and Fragrance Volatiles by Glass Capillary Gas Chromatography; Academic Press: New York, NY, USA, 1980.

26. Davies, N.W. Gas chromatographic retention indices of monoterpenes and sesquiterpenes on methyl silicone and Carbowax 20M phases. J. Chromatogr. 1990, 503, 1-24.

27. Adams, R.P. Identification of Essential Oil Components by Gas Chromatography/Mass Spectroscopy, 4th ed.; Allured Publishing: Carol Stream, IL, USA, 2007. 
28. Bewley, D.; Black, M. Seeds: Physiology of Development and Germination; Plenum Press: New York, NY, USA, 1985.

29. Sokal, R.R.; Rohlf, F.J. Biometry, 2nd ed.; W.H. Freeman and Company: New York, NY, USA, 1981.

30. Barry, A. The Antimicrobic Susceptibility Test: Principles and Practices; Lea and Febiger: Philadelphia, PA, USA, 1976.

31. Bonsignore, L.; Loy, G.; Secci, D.; Delogu, A.; Palmieri, G. A preliminary microbiological screening of Sardinian pants. Fitoterapia 1990, 61, 339-341.

32. Koneman, E.W.; Allen, S.D.; Janda, W.M.; Schreckenberg, P.C.; Winn, W.C. Color Atlas and Textbook of Diagnostic Microbiology; Lippincott-Raven: Philadelphia, PA, USA, 1997; pp. 784-785.

(C) 2012 by the authors; licensee MDPI, Basel, Switzerland. This article is an open access article distributed under the terms and conditions of the Creative Commons Attribution license (http://creativecommons.org/licenses/by/3.0/). 